\title{
Thermoseed hyperthermia treatment of mammary orthotopic transplantation tumors in rats and impact on immune function
}

\author{
WEIWEI OUYANG ${ }^{1,2}$, FUPING GAO ${ }^{2}$, LUFANG WANG ${ }^{2,3}$, XIAOXUE XIE $^{1,2}$, FENGLIN LEI $^{2}$, \\ JUMEI ZHOU ${ }^{1,2}$, YUPING LIAO ${ }^{1}$, MEIZUO ZHONG ${ }^{1}$ and JINTIAN TANG ${ }^{2}$
}

\author{
${ }^{1}$ Department of Oncology, Xiangya Hospital, Central South University, Changsha 410078; ${ }^{2}$ Key Laboratory of Particle and \\ Radiation Imaging, Ministry of Education, Institute of Medical Physics and Engineering, Department of Engineering Physics, \\ Tsinghua University, Beijing 100084; ${ }^{3}$ Department of Oncology, Anhui Provincial Hospital, Hefei 230001, P.R. China
}

Received March 30, 2010; Accepted June 18, 2010

DOI: 10.3892/or_00000944

\begin{abstract}
To evaluate the effect of thermoseed inductive heating on mammary orthotopic transplantation tumors and immunologic function in rats. Walker-256 tumor cells were inoculated subcutaneously into the mammary glands of Wistar rats. Rats were allocated to five treatment groups as follows: i) C group (control group); ii) M group (magnetic field group); iii) $\mathrm{T}$ group (thermoseed control group); iv) $\mathrm{H}_{1}$ group (hyperthermia treatment, $45^{\circ} \mathrm{C}$ for $30 \mathrm{~min}$ ); v) $\mathrm{H}_{2}$ group (hyperthermia treatment, $50-55^{\circ} \mathrm{C}$ for $\left.10 \mathrm{~min}\right)$. Immediately, 12 and $24 \mathrm{~h}$ after hyperthermia, two rats were sacrificed in each group for pathological and immunohistochemical examination of the expression of PCNA and HSP70. Tumor volume was measured and long-term survival was observed. The T lymphocyte subgroup IL-2 and IFN- $\gamma$ levels were measured in $\mathrm{C}, \mathrm{H}_{1}$ and $\mathrm{H}_{2}$ groups. Both types of hyperthermia induced necrosis and apoptosis in the tumor tissue, decreased tumor volume $(\mathrm{P}<0.05)$, and increased survival time $(\mathrm{P}<0.01)$. The expression of PCNA and HSP70 in hyperthermia group was significantly different compared to the $\mathrm{C}, \mathrm{M}$ and $\mathrm{T}$ groups $(\mathrm{P}<0.05)$, Hyperthermia increased $\mathrm{CD}^{+} \mathrm{T}$ lymphocytes and the levels of IL-2 and IFN- $\gamma(\mathrm{P}<0.05)$. Both types of hyperthermia can suppress the growth of mammary tumors and improve immunological function of rats.
\end{abstract}

\section{Introduction}

Thermoseed inductive heating arose from radiofrequency ablation (RF) technology but has advantages over radio frequency, microwave and ultrasonic wave methods. In this method, thermoseeds are implanted into tumors and then

Correspondence to: Dr Jintian Tang, Key Laboratory of Particle and Radiation Imaging, Ministry of Education, Institute of Medical Physics and Engineering Department of Engineering Physics, Tsinghua University, Beijing 100084, P.R. China

E-mail: tangjt@mail.tsinghua.edu.cn

Key words: thermoseed, hyperthermia, mammary tumor, immunological function hyperthermia is produced under an alternating magnetic field. The focused thermal energy on the tumor prevents damage to normal tissue, reduces heating time, shows uniform heat distribution and is minimally invasive $(1,2)$. A single thermoseed can be heated repeatedly to produce therapeutic efficiency similar to surgery (3), with good efficacy and safety in animal experiments $(4,5)$ and clinical research in brain tumors $(6)$ and prostatic cancer $(7,8)$.

Hyperthermia has been used for many years to treat a wide variety of tumors in both experimental animals and patients (9-11). It is reported that hyperthermia can directly induce cell damage, necrosis or apoptosis (11-13) as well as activate immunological function $(10,11)$. Hyperthermia methods include conventional hyperthermia $\left(42-45^{\circ} \mathrm{C}\right)(14)$, sub-hyperthermia $\left(39.5-41^{\circ} \mathrm{C}\right)(15)$ and thermal ablation $\left(>50^{\circ} \mathrm{C}\right)(16)$. Conventional hyperthermia and thermal ablation are useful for treating regional tumors. Ferromagnetic thermoseed hyperthermia has not been reported in mammary cancer treatment. In this study, we orthotopically transplanted Walker-256 mammary cancer cells to induce tumors in the rat mammary gland. Ferromagnetic thermoseeds at a Curie point of $61^{\circ} \mathrm{C}$ may reach $45^{\circ} \mathrm{C}$ for conventional hyperthermia or a Curie point of $78^{\circ} \mathrm{C}$ may reach $50-55^{\circ} \mathrm{C}$ for thermal ablation. We treated the mammary tumors with conventional hyperthermia or thermal ablation to evaluate the effect of heating on tumor growth and immunologic function of rats.

\section{Materials and methods}

Establishment of the animal tumor model. One hundred female Wistar rats, 6-7 weeks old, were provided by the Laboratory Animal Center of the Chinese Academy of Medical Sciences. The use of animals was conducted in compliance with the laws and regulations as well as the principles expressed in Guide for the Care and Use of Laboratory Animals of China. The Walker-256 tumor cell line was purchased from the Institute of Materia Medica, Chinese Academy of Medical Sciences and Peking Union Medical College. Walker-256 cells were injected into the abdominal cavity, and one week later, the abdominal cavity was full of ascitic fluid. The ascitic fluid was centrifuged (3-18 K, Sigma) at $1200 \mathrm{rpm}$ for $7 \mathrm{~min}$ and the tumor cells were diluted with physiological saline. The cell suspension $\left(1 \times 10^{7} / \mathrm{ml}, 0.2 \mathrm{ml}\right)$ 
was subcutaneously injected into mammary glands of the right anterior part of chest. Seven days later, 89 rats whose tumors had reached $1.5-2.0 \mathrm{~cm}$ were randomly divided into 5 groups: $\mathrm{C}$ group (control group, $\mathrm{n}=19$ ); $\mathrm{M}$ group (magnetic field group, $\mathrm{n}=14)$ : rats was placed in a magnetic field (magnetic-induction hyper-thermal machine, frequency, 100 $\mathrm{kHz}$; magnetic induction intensity, $130 \mathrm{Gs}$, Tsinghua University) for $30 \mathrm{~min}$; T group (thermoseed control group, $\mathrm{n}=14$ ): 2 thermoseeds (gold-plated, nickel-copper alloy; diameter, $0.8 \mathrm{~mm}$; length, $0.6 \mathrm{~cm}$, spaced at $1 \mathrm{~cm}$; Institute of Metal Physics at the University of Science and Technology, Beijing) were implanted into tumors; $\mathrm{H}$ group (hyperthermia group; $\mathrm{H}_{1}, \mathrm{n}=21$ and $\mathrm{H}_{2}, \mathrm{n}=21$ ) had 2 subgroups: $\mathrm{H}_{1}$ group received 3-4 thermoseeds (spaced $1 \mathrm{~cm}$ ) with a Curie point of $61^{\circ} \mathrm{C}$, and in $\mathrm{H}_{2}$ group thermoseeds had Curie points of $78^{\circ} \mathrm{C}$. The heating time was 30 min for $\mathrm{H}_{1}$ group and 10 min for $\mathrm{H}_{2}$ group.

Effect of hyperthermia on tumor-bearing rats. The influence of hyperthermia on tumor volume changes and survival time of rats was observed. The $\mathrm{C}, \mathrm{M}$ and $\mathrm{T}$ groups had 8 rats each, and the $\mathrm{H}_{1}$ and $\mathrm{H}_{2}$ groups have 10 each. $\mathrm{In}_{1}$ and $\mathrm{H}_{2}$, the long axis of the implanted thermoseeds was parallel with the direction of the alternating magnetic field; three thermocouples (It-18 copper-constantan thermocouple manufactured by Physitemp, $1 \mathrm{~mm}$ diameter and $0.1 \mathrm{sec}$ temperature response time) connected to a 4-channel temperature indicator (XS01A-4, Beijing Kunlun Tianchen Instrument Science and Technology Co., Ltd.) were used to monitor temperature changes in the tumor center, tumor edge and body temperature (rectal temperature). Tumor volume, defined as $\mathrm{V}=\left(\mathrm{axb}^{2}\right) / 2$, where $\mathrm{a}$ is the maximum diameter horizontally and $\mathrm{b}$ is the maximum diameter vertically, was measured 14 days after hyperthermia. Survival time was also measured.

Pathological examination and immunohistochemical analysis. Immediately, 12 and $24 \mathrm{~h}$ after thermotherapy respectively, 2 rats were sacrificed in each group by neck dislocation, and tumor tissue specimens were fixed in $10 \%$ neutrally buffered formalin, then embedded in paraffin for routine H\&E staining, immunohistochemistry for PCNA (provided by Beijing Zhongshan Goldenbridge Biotechnology Co., Ltd.) and HSP70 (provided by Wuhan Boster Biological Technology Ltd.). PCNA and HSP70 staining were quantified by staining intensity and the percentage of positive cells. Five areas were randomly selected for counting under 400-fold magnification (17). Staining intensity scores: 0 , no color; 1 , yellow; 2 , brown; 3 , dark brown. The percentage of positive cells was counted: $0,0 \%$ positive cell; $1, \leq 25 \%$ positive cells; $2, \leq 50 \%$ positive cells; $3,>50 \%$ positive cells; minimum value $=0$, maximum value $=6$.

Flow cytometry and ELISA analysis. Five rats came from C, $\mathrm{H}_{1}$ and $\mathrm{H}_{2}$ group, respectively. Fourteen days after thermotherapy, rats were sacrificed and peripheral blood was collected. Heparin was used to anticoagulate peripheral blood $(1 \mathrm{ml})$, and density gradient centrifugation was used to centrifugate lymphocytes from $0.2 \mathrm{ml}$ serum. Cell density was adjusted to $1 \times 10^{6}$ cells $/ \mathrm{ml}$, and $\mathrm{T}$ lymphocyte subgroups, $\mathrm{CD}^{+}$and $\mathrm{CD}^{+}$(eBioscience, San Diego, USA), were

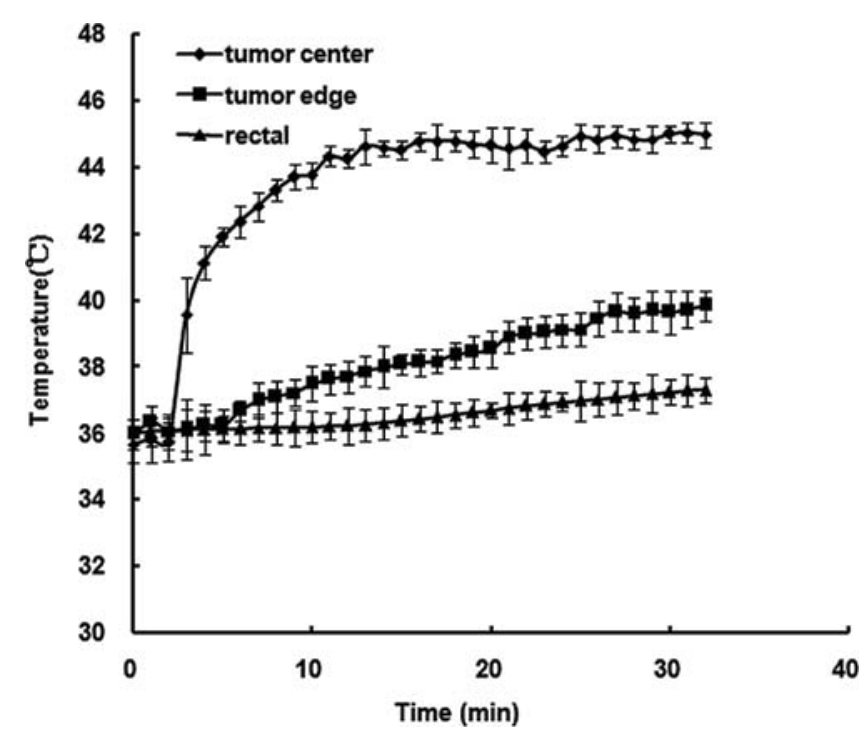

Figure 1. Temperature curve of $\mathrm{H}_{1}$ group (thermoseeds with a Curie point of $61^{\circ} \mathrm{C}$, heated for $30 \mathrm{~min}$, heating operation began at the $2 \mathrm{nd}$ minute and ended at the $32 \mathrm{nd}$ minute), $(\mathrm{n}=10)$.

measured with a flow cytometer (Becton-Dickinson, USA). ELISA was used to measure the levels of IL-2 and IFN- $\gamma$ in $0.2 \mathrm{ml}$ serum (IL-2 and IFN- $\gamma$ kits were purchased from R\&D System). An ELISA reader was used to measure the OD450 (Bio-Rad 680, Hercules, CA) for calculation of sample concentration.

Statistical analysis. SPSS10.0 software was used for datas analysis, and data were expressed as mean \pm SD. ANOVA analysis was used for multiple comparisons, but data with non-normal distribution and heteroschedasticity (e.g., a minimum-maximal value) were analyzed with the nonparametric rank-sum test. The Kaplan-Meier log-rank test was used to calculate survival rate. Significance levels were set at $\mathrm{P}<0.05$.

\section{Results}

Mammary cancer model in rats. Walker 256 cells produced large, homogeneous, invasive tumors in $89 \%$ of rats. Papillae was in the middle of the outstanding tumor, which was suitable for thermoseed implantation hyperthermia. Tumor cells invaded the breast tissue to produce hyperplasia and heteromorphic changes in breast epithelium (Fig. 5B).

Thermoseed temperature measurement after implantation. Tumor temperatures in $\mathrm{H}_{1}$ started at $(35.7 \pm 0.6)^{\circ} \mathrm{C}$, reached $(41.9 \pm 0.3)^{\circ} \mathrm{C}$ after $3 \mathrm{~min}$ of heating, and then reached plateau at $44-45^{\circ} \mathrm{C}$ (Fig. 1). Normal tissue in tumor edge heated slowly to $(39.8 \pm 0.4)^{\circ} \mathrm{C}$, but rectal temperature remained at $36-37.3^{\circ} \mathrm{C}$. The temperatures of tumor center in $\mathrm{H}_{2}$ reached $51 \pm 0.5^{\circ} \mathrm{C}$ after $5 \mathrm{~min}$ of heating and reached plateau at 54$55^{\circ} \mathrm{C}$ (Fig. 2). The temperatures of normal tissue in tumor edge reached $39.4 \pm 0.4^{\circ} \mathrm{C}$ at the end of heating and rectal temperature remained approximately at $36^{\circ} \mathrm{C}$ during hyperthermia. 


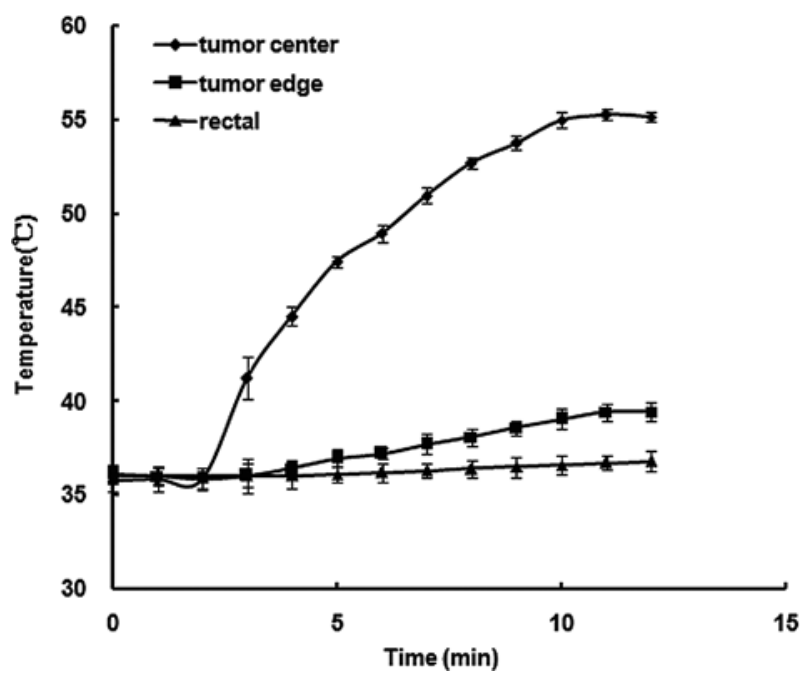

Figure 2. Temperature curve of $\mathrm{H}_{2}$ group (thermoseeds with a Curie point of $78^{\circ} \mathrm{C}$, heated for $10 \mathrm{~min}$, heating operation began at the $2 \mathrm{nd}$ minute and ended at the 12 th minute $),(n=10)$.

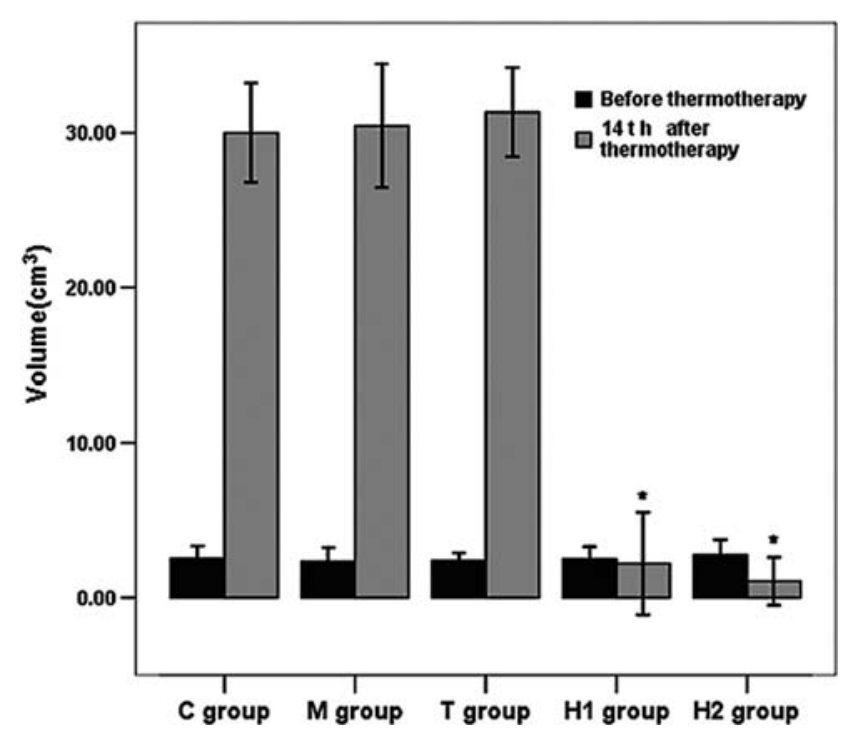

Figure 3. Tumor volumes before and after hyperthermia. *Compared with $\mathrm{C}$, $\mathrm{M}$ and $\mathrm{T}$ group 14 days after the hyperthermia, $\mathrm{P}<0.05$.

\section{The effect of hyperthermia on tumors}

Influence of hyperthermia on tumor volumes of rats. Tumor volumes were not different before magnetic-induction heating. Hyperthermia reduced tumor volume 14 days after heating, with $\mathrm{H}_{1}\left(0-8.50 \mathrm{~cm}^{3}\right), \mathrm{H}_{2}\left(0-4.37 \mathrm{~cm}^{3}\right), \mathrm{C}\left(26.25-35.52 \mathrm{~cm}^{3}\right)$, M (25.04-36.53 $\left.\mathrm{cm}^{3}\right)$ and $\mathrm{T}\left(27.32-35.69 \mathrm{~cm}^{3}\right)\left(\mathrm{H}_{1}\right.$ and $\mathrm{H}_{2}$ vs. C, $\mathrm{M}$ and T; $\mathrm{P}<0.05$; Fig. 3$)$.

Influence of hyperthermia on survival period of rats. As shown in Fig. 4, the survival period of tumor-bearing rats was observed for 390 days after tumor implantation. The tumor volumes of $\mathrm{C}, \mathrm{M}$ and $\mathrm{T}$ groups rats grew rapidly and all the rats died by 47,45 and 41 days, respectively. The survival period of $\mathrm{C}, \mathrm{M}$ and $\mathrm{T}$ groups was $(32.75 \pm 7.78)$, $(32.00 \pm 7.39)$ and $(29.88 \pm 5.82)$ days, respectively. Three rats

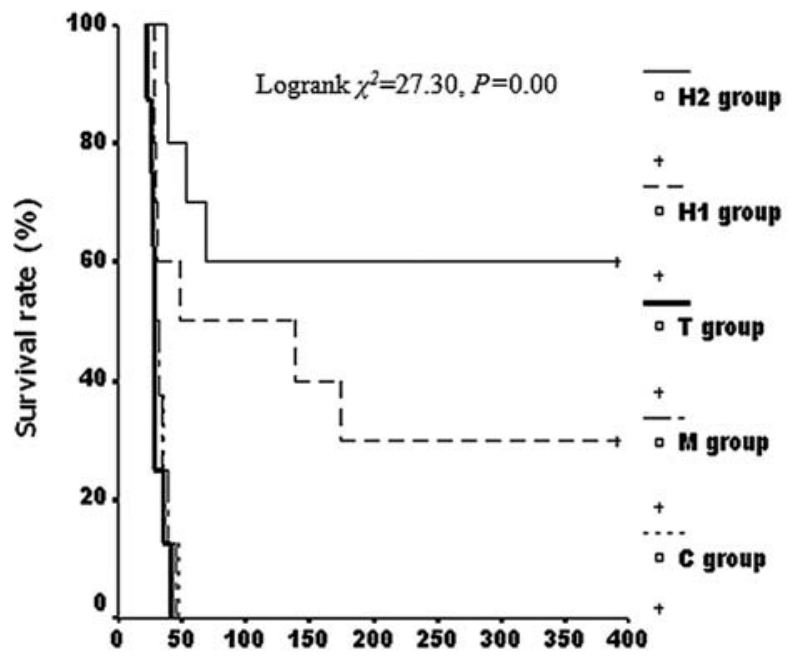

\section{Days after tumor implantation}

Figure 4. Survival rate after tumor implantation.

in $\mathrm{H}_{1}$ group and 6 rats in $\mathrm{H}_{2}$ group were cured and alive 390 days after tumor implantation $(\mathrm{P}<0.01$ vs. $\mathrm{C}, \mathrm{M}$ and $\mathrm{T}$ group, but no difference between $\mathrm{H}_{1}$ and $\mathrm{H}_{2}$ group).

Pathological observation and immunohistochemical analysis Pathological observation. Cancer cells invaded mammary tissue and caused epithelial proliferation with multilayer, nuclear atypia changes (Fig. 5A, B). Tumor tissues in $\mathrm{H}_{1}$ and $\mathrm{H}_{2}$ group showed changes in coagulation and necrosis after heating, with acidophilic staining, loss of cytoarchitecture and nucleus, debris formation and morphologic variation such as nuclear pyknosis and chromatin agglutination and thickening (Fig. 5C). Tumor tissue showed high formation of blood vessels (Fig. 5D). A rat in $\mathrm{H}_{1}$ group showed large amounts of tumor necrosis $24 \mathrm{~h}$ after hyperthermia, but still showed residual tumor cells at the tumor edge (Fig. 5E). One rat in $\mathrm{H}_{2}$ group showed complete tumor necrosis $24 \mathrm{~h}$ after hyperthermia and necrotized mammary gland (Fig. 5F).

Immunohistochemical analysis. Nuclear and cytoplasmic HSP70 expression were high in all groups and increased immediately after heating, but decreased to lower levels than control groups $(\mathrm{P}<0.05)$ as tumor cells entered apoptosis and necrosis. Similarly, nuclear PCNA staining was initially high in tumor cells, but diminished immediately after heating to lower levels than control group $(\mathrm{P}<0.05)$ (Tables I and II).

Influence of hyperthermia on T lymphocyte subgroup. Heating increased $\mathrm{CD}^{+} \mathrm{T}$ lymphocytes more than $\mathrm{C}$ group $(\mathrm{P}<0.05)$, but the two hyperthermia groups were also different $(\mathrm{P}<0.05)$. The $\mathrm{CD}^{+} / \mathrm{CD}^{+}$ratio for $\mathrm{H}_{1}$ and $\mathrm{H}_{2}$ group were higher than $\mathrm{C}$ group $(\mathrm{P}<0.05)$, and that of $\mathrm{H}_{1}$ and $\mathrm{H}_{2}$ group were also different $(\mathrm{P}<0.05$; Table III).

Effect of hyperthermia on IL-2 and IFN- $\gamma$. Hyperthermia significantly increased IL-2 levels in serum, with $\mathrm{H}_{1}$ group (26.27 \pm 2.80$) \mathrm{pg} / \mathrm{ml}, \mathrm{H}_{2}$ group $(23.38 \pm 3.67) \mathrm{pg} / \mathrm{ml}$ and $\mathrm{C}$ 

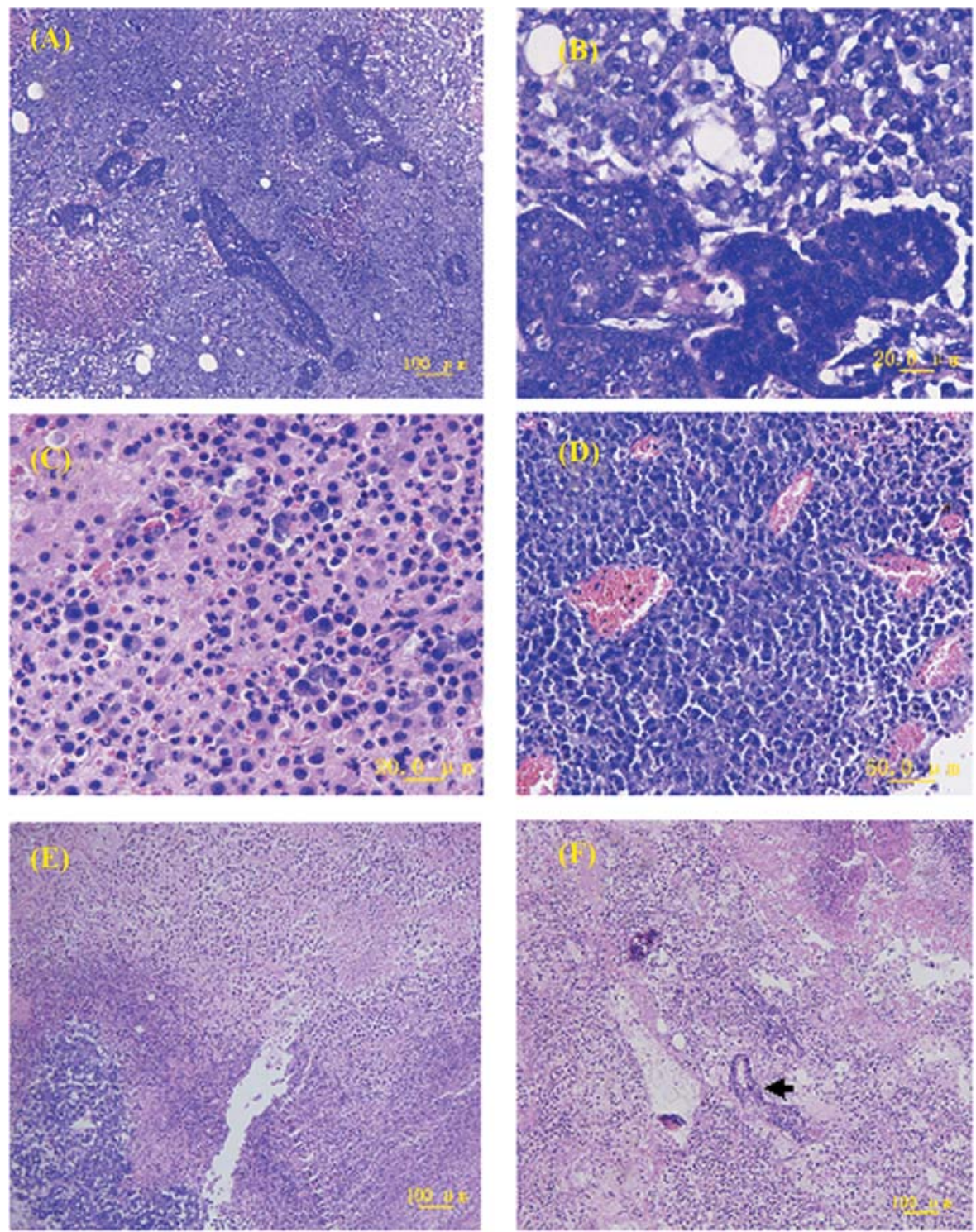

Figure 5. Pathologic changes in mammary tumor tissue. (A) Large tumor tissue invades the mammary gland; (B) Tumor tissue invades the mammary tissue, showing that mammary epithelia proliferate and nuclear atypia change; (C) Tumor tissue shows apoptosis and necrotizes immediately after heating treatment; (D) After 30 min of heating at $45^{\circ} \mathrm{C}$, tumor tissue necrotizes in a large area and small vessels expand because of congestion; (E) Pathologic changes can be seen $24 \mathrm{~h}$ after heating at $45^{\circ} \mathrm{C}$, the tumor necrotizes in a large area, leaving residual tumor tissue at the edge; (F) Complete tumor tissue necrosis at $24 \mathrm{~h}$ after treatment at $50-55^{\circ} \mathrm{C}$, and necrotized mammary gland (arrow).

group $(13.15 \pm 3.11) \mathrm{pg} / \mathrm{ml}(\mathrm{P}<0.05)$. Hyperthermia also Table I. Expression of HSP70.

\begin{tabular}{lccc}
\hline Groups & $\begin{array}{c}\text { Immediately after } \\
\text { thermotherapy }\end{array}$ & $\begin{array}{c}12 \mathrm{~h} \text { after } \\
\text { thermotherapy }\end{array}$ & $\begin{array}{c}24 \mathrm{~h} \text { after } \\
\text { thermotherapy }\end{array}$ \\
\hline $\mathrm{C}$ & $3.10 \pm 0.88$ & $2.90 \pm 0.57$ & $2.90 \pm 0.57$ \\
$\mathrm{M}$ & $3.10 \pm 0.74$ & $2.80 \pm 0.42$ & $2.80 \pm 0.79$ \\
$\mathrm{~T}$ & $2.90 \pm 0.88$ & $3.10 \pm 0.99$ & $2.70 \pm 0.82$ \\
$\mathrm{H}_{1}$ & $4.40 \pm 0.97^{\mathrm{a}}$ & $1.50 \pm 0.85^{\mathrm{a}}$ & $1.00 \pm 0.67^{\mathrm{a}}$ \\
$\mathrm{H}_{2}$ & $4.30 \pm 0.95^{\mathrm{a}}$ & $1.10 \pm 0.74^{\mathrm{a}}$ & $1.00 \pm 0.82^{\mathrm{a}}$ \\
\hline
\end{tabular}

${ }^{a} \mathrm{P}<0.05$ compared with $\mathrm{C}, \mathrm{M}$ and $\mathrm{T}$ groups in each time-point.
Table II. Expression of PCNA.

\begin{tabular}{lccc}
\hline Groups & $\begin{array}{c}\text { Immediately after } \\
\text { thermotherapy }\end{array}$ & $\begin{array}{c}12 \mathrm{~h} \text { after } \\
\text { thermotherapy }\end{array}$ & $\begin{array}{c}24 \mathrm{~h} \text { after } \\
\text { thermotherapy }\end{array}$ \\
\hline $\mathrm{C}$ & $4.00 \pm 0.82$ & $4.20 \pm 0.79$ & $4.00 \pm 0.94$ \\
$\mathrm{M}$ & $4.20 \pm 0.79$ & $3.60 \pm 0.70$ & $3.80 \pm 0.79$ \\
$\mathrm{~T}$ & $3.90 \pm 0.99$ & $3.70 \pm 0.68$ & $3.80 \pm 0.92$ \\
$\mathrm{H}_{1}$ & $3.00 \pm 0.82^{\mathrm{a}}$ & $1.10 \pm 0.74^{\mathrm{a}}$ & $1.00 \pm 0.67^{\mathrm{a}}$ \\
$\mathrm{H}_{2}$ & $3.30 \pm 0.95^{\mathrm{b}}$ & $1.00 \pm 0.67^{\mathrm{a}}$ & $0.90 \pm 0.74^{\mathrm{a}}$ \\
\hline
\end{tabular}

${ }^{\mathrm{a}} \mathrm{P}<0.05$ compared with $\mathrm{C}, \mathrm{M}$ and $\mathrm{T}$ groups in each time-point; ${ }^{\mathrm{b}} \mathrm{P}<0.05$ compared with $\mathrm{M}$ group immediately after thermotherapy. 

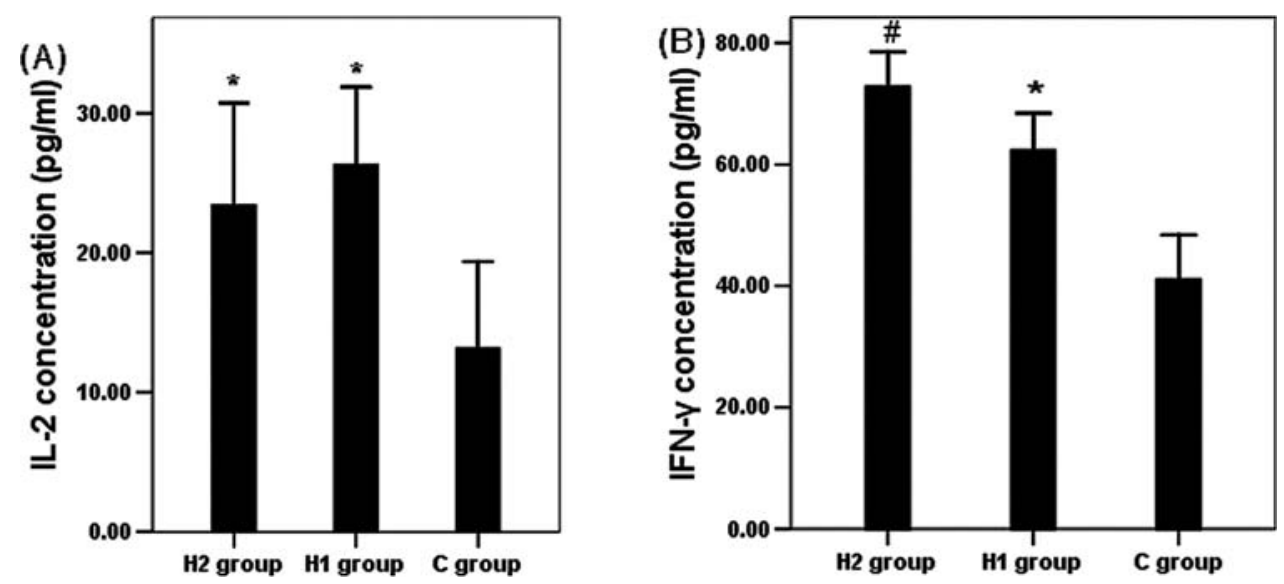

Figure 6. Cytokine levels in peripheral blood. (A) IL-2 levels in peripheral blood were detected by IL-2 ELISA kit. "P<0.05 compared with C group. (B) IFN- $\gamma$ levels in peripheral blood were detected by IFN- $\gamma$ ELISA kit. ${ }^{*} \mathrm{P}<0.05$ compared with $\mathrm{C}$ group; ${ }^{~} \mathrm{P}<0.05$ compared with $\mathrm{C}$ and $\mathrm{H}_{1}$ group.

Table III. Comparison of T lymphocyte subgroups in peripheral blood.

\begin{tabular}{llll}
\hline Groups & $\mathrm{CD}^{+}(\%)$ & $\mathrm{CD}^{+}(\%)$ & $\mathrm{CD}^{+} / \mathrm{CD}^{+}$ \\
\hline $\mathrm{C}$ & $15.87 \pm 2.11^{\mathrm{a}}$ & $16.83 \pm 1.56$ & $0.96 \pm 0.20^{\mathrm{a}}$ \\
$\mathrm{H}_{1}$ & $28.62 \pm 4.21$ & $16.99 \pm 1.29$ & $1.68 \pm 0.18$ \\
$\mathrm{H}_{2}$ & $23.41 \pm 2.15^{\mathrm{b}}$ & $17.32 \pm 1.35$ & $1.35 \pm 0.11^{\mathrm{b}}$ \\
\hline
\end{tabular}

$\mathrm{n}=5$, ${ }^{\mathrm{a}} \mathrm{P}<0.05$ compared with $\mathrm{H}_{1}$ and $\mathrm{H}_{2}$ groups; ${ }^{\mathrm{b}} \mathrm{P}<0.05$ compared with $\mathrm{H}_{1}$ group.

increased serum IFN- $\gamma$ levels, with $\mathrm{H}_{1}$ group $(62.33 \pm 3.01)$ $\mathrm{pg} / \mathrm{ml}, \mathrm{H}_{2}$ group $(72.78 \pm 2.88) \mathrm{pg} / \mathrm{ml}$ and $\mathrm{C}$ group $(41.07 \pm 3.65)$ $\mathrm{pg} / \mathrm{ml}(\mathrm{P}<0.05)$. IFN- $\gamma$ levels of $\mathrm{H}_{2}$ group was significantly higher than $\mathrm{H}_{1}$ group ( $\mathrm{P}<0.05$; Fig. 6).

\section{Discussion}

Progress in material science, temperature measurement technology (18) and magnetic field equipment allowed development of magnetic induction hyperthermia as a tumor treatment. Thermoseeds are a special alloy made from a nonmagnetic substance and magnetic metal that restricts the maximum temperature by the Curie point. Thermoseeds with a narrow range of Curie points (generally several degrees Centigrade) produce better effects in tumor treatment. The gold-plated, nickel-copper alloy thermoseed could reach its Curie point temperature. Gold plating thermoseed have good biocompatibility, and the length $(6 \mathrm{~mm})$ allows accurate implantation with an implantation gun. Thermoseed treatment of malignant tumor of the biliary duct and advanced cancer of the esophagus are being pursued in clinical trials $(19,20)$.

Mammary cancer is the most common malignant tumor in women in most developed countries. In China, the incidence of mammary cancer increases at an annual rate of 3\%, and is the most common malignant tumor in women in large cities (21). The therapeutic concept of mammary cancer has changed from 'maximum tolerated' to 'minimally effective' $(22,23)$, and magnetic induction hyperthermia complies with this therapeutic mode. The mammary location allows thermoseeds to be implanted easily and located accurately. Thermoseeds are regarded as a new method to combined modality therapy. It is minimally invasive and displays a high safety profile. Thus, it is possible to prolong survival of patients and improve the quality of life.

We inoculated mammary cancer cells into the mammary gland to produce invasive tumors that induce mammary epithelial proliferation and nuclear atypia. Hyperthermia treatment caused tumor cells apoptosis and necrosis, with complete tumor tissues necrosis in some rats within $24 \mathrm{~h}$, consistent with Tucker et al (3). Hyperthermia also decreased PCNA expression. PCNA is a cyclin critical for eukaryotic DNA synthesis that associates with DNA polymerase D and influences tumor metastasis (24). Hyperthermia can also improve immunological function as it induces tumor cells to produce antigenic HSPs (25). HSPs can produce a signal to activate dendritic cells and induce protective immunity (26). HSP70 can strengthen the reaction of $\mathrm{CD} 4^{+} \mathrm{T}$ cells to MHC II stimuli (27) by making $\mathrm{T}$ cells, macrophages and dendritic cells to infiltrate tumor tissue and stimulate production of the cytokines, IFN- $\gamma$, TNF- $\alpha$ and IL-12 (28). CD4 ${ }^{+}$T cells help generate an effective immune response with T helper 1 (Th1) and Th2 cells (29). CD4 ${ }^{+} \mathrm{T}$ cells perform immunological surveillance and regulation, and a consistent CD4/CD8 ratio maintains the balance of cell-mediated immunity. Therefore, the $\mathrm{CD} 4 / \mathrm{CD} 8$ ratio is an important index of anti-tumoral immune function (30). Here, hyperthermia increased $\mathrm{CD} 4^{+} \mathrm{T}$ lymphocytes and the ratio of CD4/CD8 cells. Interleukin-2 (IL-2) is a potent stimulator of lymphocyte proliferation and cytotoxic $\mathrm{T}$ lymphocytes and used in cancer therapy to enhance cellular immunity and the cytotoxic activity of effector cells (31). IFN- $\gamma$ can inhibit tumor growth, recurrence and metastasis by inducing apoptosis, inhibiting cell proliferation and differentiation, inhibiting tumor angiogenesis 
and regulating immune responses $(32,33)$. Hyperthermia increased levels of IL- 2 and IFN- $\gamma$ and Th1 cell activity $(10,34) . \mathrm{CD}^{+} \mathrm{T}$ cells in $\mathrm{H}_{1}$ group were higher than in $\mathrm{H}_{2}$ group, but IFN- $\gamma$ levels in $\mathrm{H}_{2}$ group were higher than in $\mathrm{H}_{1}$ group, potentially due to differences in treatment temperature. Specifics need further investigation. Three rats in $\mathrm{H}_{1}$ group and 6 rats in $\mathrm{H}_{2}$ group were cured, but other cases have developed local uncontrolled growth or recurrence. $\mathrm{H}_{2}$ group seems to have advantage over $\mathrm{H}_{1}$ group, which needs further research. Repeated hyperthermia may show longer-term inhibition of tumor growth and potentiation of immunological function.

Tumor temperatures reached $45^{\circ} \mathrm{C}$ in $\mathrm{H}_{1}$ group and $55^{\circ} \mathrm{C}$ in $\mathrm{H}_{2}$ group, temperature increased rapidly, but normal tissue did not exceed $40^{\circ} \mathrm{C}$. This specificity and control of temperature is an advantage over other methods. Ultrasonic wave is not through gas-bearing cavity, it can be reflected and absorbed by bone. Radiofrequency show excess heating of subcutaneous fat, unexpected heating caused by edge effects and insufficient penetration (13). Thermoseed characteristics, such as self-controlled temperature, internal heating and repeatability, increase the accuracy and safety of tumor treatments by hyperthermia.

In conclusion, both thermoseed induction hyperthermia methods could inhibit tumor growth and improve immune function in vivo. Hyperthermia caused tumor tissues to undergo apoptosis and necrosis and reduced PCNA expression, indicating growth inhibition. Hyperthermia increased the population of $\mathrm{CD}^{+} \mathrm{T}$ lymphocytes, probably after upregulation of HSP70, IL-2 and IFN- $\gamma$. Hyperthermia seemed well tolerated and reasonably safe, providing a basis for future clinical research on mammary cancer.

\section{Acknowledgements}

This study was supported by the National Natural Science Foundation of China (30571779, 10775085), Beijing Municipal Science and Technology Commission (No. Z07000200540704) and Yuyuan Medical Foundation of Tsinghua University. We thank Dr Zhao Tiande and Dr Pan Lin (Department of Pathology in Institution of Clinical Research of China-Japan Friendship Hospital) for their support.

\section{References}

1. Steeves RA, Murray TG, Moros EG, Boldt HC, Mieler WF and Paliwal BR: Concurrent ferromagnetic hyperthermia and I-125 brachytherapy in a rabbit choroidal melanoma model. Int $\mathbf{J}$ Hyperthermia 8: 443-449, 1992.

2. Rehman J, Landman J, Tucker RD, Bostwick DG, Sundaram CP and Clayman RV: Ferromagnetic self-regulating reheatable thermal rod for in situ tissue ablation. J Endourol 16: 523-531, 2002.

3. Tucker RD, Platz CE, Huidobro C and Larson T: Interstitial thermal therapy in patients with localized prostate cancer: histologic analysis. Urology 60: 166-169, 2002.

4. Akagi M, Tsuboyama T, Ikenaga M, Matsusue Y, Hiraoka M and Nakamura T: Anti-tumour effects of localized hyperthermia on an experimental bone tumour using an intramedullary nail. Int J Hyperthermia 13: 387-400, 1997.

5. Murray TG, O'Brien JM, Steeves RA, et al: Radiation therapy and ferromagnetic hyperthermia in the treatment of murine transgenic retinoblastoma. Arch Ophthalmol 114: 1376-1381, 1996.
6. Stea B, Rossman K, Kittelson J, Shetter A, Hamilton A and Cassady JR: Interstitial irradiation versus interstitial thermoradiotherapy for supratentorial malignant gliomas: a comparative survival analysis. Int J Radiat Oncol Biol Phys 30: 591-600, 1994.

7. Master VA, Shinohara K and Carroll PR: Ferromagnetic thermal ablation of locally recurrent prostate cancer: prostate specific antigen results and immediate/intermediate morbidities. J Urol 172: 2197-2202, 2004.

8. Tucker RD, Huidobro C and Larson T: Ablation of stage T-1/T-2 prostate cancer with permanent interstitial temperature selfregulating rods. J Endourol 19: 865-867, 2005.

9. Johannsen M, Thiesen B, Jordan A, et al: Magnetic fluid hyperthermia (MFH) reduces prostate cancer growth in the orthotopic dunning R3327 rat model. Prostate 64: 283-292, 2005.

10. Guo J, Zhu J, Sheng XN, et al: Intratumoral injection of dendritic cells in combination with local hyperthermia induces systemic antitumor effect in patients with advanced melanoma. Int J Cancer 120: 2418-2425, 2007.

11. Lu P, Zhu XQ, Xu ZL, Zhou Q, Zhang J and Wu F: Increased infiltration of activated tumor-infiltrating lymphocytes after high intensity focused ultrasound ablation of human breast cancer. Surgery 145: 286-293, 2009.

12. Rong Y and Mack P: Apoptosis induced by hyperthermia in Dunn osteosarcoma cell line in vitro. Int J Hyperthermia 16: 19-27, 2000.

13. Saito H, Mitobe K, Ito A, et al: Self-regulating hyperthermia induced using thermosensitive ferromagnetic material with a low Curie temperature. Cancer Sci 99: 805-809, 2008.

14. Thompson JF and Kam PCA: Current status of isolated limb infusion with mild hyperthermia for melanoma. Int $\mathrm{J}$ Hyperthermia 24: 219-225, 2008.

15. Atmaca A, Al-Batran SE, Neumann A, Kolassa Y, Jager D, Knuth A and Jager E: Whole-body hyperthermia (WBH) in combination with carboplatin in patients with recurrent ovarian cancer - a phase II study. Gynecol Oncol 112: 384$388,2009$.

16. Park S, Cadeddu JA and Shingleton WB: Oncologic outcomes for ablative therapy of kidney cancer. Curr Urol Rep 8: 31-37, 2007.

17. Kawasaki H, Toyoda M, Shinohara H, et al: Expression of survivin correlates with apoptosis, proliferation and angiogenesis during human colorectal tumorigenesis. Cancer 91: 2026-2032, 2001 .

18. Johannsen M, Gneueckow U, Thiesen B, et al: Thermotherapy of prostate cancer using magnetic nanoparticles: feasibility, imaging and three-dimensional temperature distribution. Eur Urol 52: 1653-1662, 2007.

19. Kamisawa T, Tu YY, Egawa N, Karasawa K, Matsuda T, Tsuruta $\mathrm{K}$ and Okamoto $\mathrm{A}$ : Thermo-chemo-radiotherapy for advanced bile duct carcinoma. World J Gastroenterol 11: 4206-4209, 2005

20. Akiyama S, Kawasaki S, Kodera Y, Hibi K, Kato S, Ito K and Nakao A: A new method of thermo-chemotherapy using a stent for patients with esophageal cancer. Surg Today 36: 19-24, 2006.

21. Yu KD, Di GH, Wu J, Lu JS, Shen KW, Shen ZZ and Shao ZM: Development and trends of surgical modalities for breast cancer in China: a review of 16-year data. Ann Surg Oncol 14: 2502-2509, 2007.

22. Hall-Craggs MA and Vaidya JS: Minimally invasive therapy for the treatment of breast tumours. Eur J Radiol 42: 52-57, 2002.

23. Singletary SE: Minimally invasive ablation techniques in breast cancer treatment. Ann Surg Oncol 9: 319-320, 2002.

24. Bantis A, Giannopoulos A, Gonidi M, et al: Expression of p120, Ki-67 and PCNA as proliferation biomarkers in imprint smears of prostate carcinoma and their prognostic value. Cytopathol 15: 25-31, 2004.

25. Li DP, Li H, Zhang PY, et al: Heat shock fusion protein induces both specific and non-specific anti-tumor immunity. Eur J Immunol 36: 1324-1336, 2006.

26. Zhang HG, Mehta K, Cohen P and Guha C: Hyperthermia on immune regulation: a temperature's story. Cancer Lett 271: 191-204, 2008.

27. Tobian AAR, Canaday DH and Harding CV: Bacterial heat shock proteins enhance class II MHC antigen processing and presentation of chaperoned peptides to CD4(+) T cells. J Immunol 173: 5130-5137, 2004 . 
28. Todryk S, Melcher AA, Hardwick N, et al: Heat shock protein 70 induced during tumor cell killing induces Th1 cytokines and targets immature dendritic cell precursors to enhance antigen uptake. J Immunol 163: 1398-1408, 1999.

29. Chamuleau MED, Ossenkoppele GJ and van de Loosdrecht AA: MHC class II molecules in tumour immunology: prognostic marker and target for immune modulation. Immunobiology 211: 619-625, 2006.

30. Mafune $\mathrm{K}$ and Tanaka Y: Influence of multimodality therapy on the cellular immunity of patients with esophageal cancer. Ann Surg Oncol 7: 609-616, 2000.

31. Ito A, Tanaka K, Kondo K, et al: Tumor regression by combined immunotherapy and hyperthermia using magnetic nanoparticles in an experimental subcutaneous murine melanoma. Cancer Sci 94: 308-313, 2003
32. Kominsky S, Johnson HM, Bryan G, Tanabe T, Hobeika AC Subramaniam PS and Torres B: IFN gamma inhibition of cell growth in glioblastomas correlates with increased levels of the cyclin-dependent kinase inhibitor p21(WAF1/CIP1). Oncogene 17: 2973-2979, 1998.

33. Yao L, Pike SE, Setsuda J, et al: Effective targeting of tumor vasculature by the angiogenesis inhibitors vasostatin and interleukin-12. Blood 96: 1900-1905, 2000.

34. Kramer G, Steiner GE, Grobl M, et al: Response to sublethal heat treatment of prostatic tumor cells and of prostatic tumor infiltrating T-cells. Prostate 58: 109-120, 2004. 